\title{
The Only Liberation Is Paternal Dominion: Discourse of the Other in Illywhacker and the Unusual Life of Tristan Smith
}

\author{
Shahram R. Sistani ${ }^{1}$ \\ ${ }^{1}$ Department of Foreign Languages, Bahonar University of Kerman, Kerman, Iran \\ Correspondence: Shahram R. Sistani, Department of Foreign Languages, Faculty of Humanities, Bahonar \\ University of Kerman, 22 Bahman Blvd, Pazhoohesh Sq, Kerman, 7616914111, Iran. Tel: 98-341-3245-9998. \\ E-mail: shahramsistani@gmail.com
}

\author{
Received: August 5, 2014 Accepted: October 15, 2014 Online Published: December 20, 2014 \\ doi:10.5539/ass.v11n2p167 URL: http://dx.doi.org/10.5539/ass.v11n2p167
}

\begin{abstract}
Peter Carey is the prominent novelist of contemporary Australia. His novels delve into the country's search for cultural subjectivity and nationalism. He uses his own style for interrogating dominant ideology which challenges people's attempts for acquiring identity. This paper is aimed to give a psycho-social analysis of the concept of the other in Illywhacker (1985) and The Unusual Life of Tristan Smith (1994). In the novels all the characters whether man or women are depicted as controlled by a phallocentric ideology. These characters in their quest for subjectivity create the other. To discuss the reasons I found Lacanian views about ideology very efficient. For the reason that Lacan assumed that unconscious is discourse of the other. In these novels characters' attempts for achieving subjectivity are frustrated due to the ideology which is prevailed in the society. Open-endedness of these novels challenges the fictionality of history and the reality depicted therein. It seems that there is a similarity between Carey's notions of imperialism and Lacan's interpretation of the real.

Carey always mixes fantasy with the real for bringing to the light some recesses of desire. This usage of fantasy brings him close to the writing of Jorge Louis Borges. The aim of this article is not to see if these fantasies are realistic or subverted but whether they can disclose something about desire and freedom. For Lacan, repression is the beginning of unconscious desire-a desire which manifests itself through the language of characters. In Illywhacker as long as Herbert tells stories and lies his business and life is secure. These fantasies of him are manifestations of the presence of the Other. Hence these novels can be considered as discourse of the Other and demonstration of desire.
\end{abstract}

Keywords: cultural imperialism, demonstration of desire, double consciousness, phallocentric ideology, subjectivity

\section{Introduction}

Peter Carey is the most celebrated novelist of contemporary Australian literature. In most of his novels he is obsessed with the history of his country. In his historiography indulgence with the dominant ideology is always a point of prominence. Carey problematizes dominant attitude of contemporary imperialism. In his postcolonial approach he benefits from postmodern techniques. By this he brought Australian literature to the level of prestigious literary products such as those of Latin America.

Illywhacker a masterpiece of Carey attempts to read twentieth century Australian history as the most beautiful lies. It deals with lots of myths and facts such as, Australia's own Car, the squatter, the entrepreneur, the workingman's paradise. The novel gives a distinctive picture of these desires and dreams and uncovers them as self-deception. Bruce Woodcock (1996) a major critic of Carey's fiction claims, "Like Bliss, Illywhacker transgresses and undermines presumptions of formal continuity and genre coherence: it both entertains and indicts as it investigates the construction of fundamental Australian mythologies, the visions, dreams and lies of the national psyche" (p. 53). Carey tries to challenge our perception of the reality around us. As he himself said to Van Ikin (1977) thus, "Do people want to, or have to, live the way they do now? What will happen to us if we keep on living like we do now?" (p. 34). There is always a concern for individual and social transformation in his novels. He uncovers a world of dreams and illusions beneath the reality. These techniques associate him with the genre of Fantastic Realism. Through which he discovers the hidden recesses of individual psyche. As such Northrop Frye (1976) believes fantasy is the most prominent channel for expressing thought for contemporary 
novelists. Specifically for those writers who are not willing to follow earlier styles. In the novels such as Illywhacker we come across with unfulfilled desires of a generation. It can be seen as a story of psychological and social transformation. It is about the change in attitude from dependence to independence. At the same time there is an affirmation on own cultural values as well. But at the same time it gives a sense of frustration to the reader. As Rosemary Jackson (1981) avers postmodern "continues to articulate absolute desire, but its ends are no longer known: breaking finite, human limits, becomes its only (im)possibility." (p. 79)

Herbert the protagonist is introduced as a story teller and the main story of the novel is about his narration of the history of the country. Regarding to this Woodcock (1996) believes, "Herbert's double role as surrogate author and dealer in lies presents him in the process of constructing his own identity and destiny, foregrounding the theme of personal and national representation" (p. 57). But the point is that all his attempts go astray. The delusion of his dreams is depicted through his childhood desire of making an Australian airplane. His purpose is to evade signs of colonial dependency but it is also a sign of continues colonialism. This idea is connected with his true capacity for telling lies.

In The Unusual Life of Tristan Smith satirical place of colonizer and colonized is more bizarre. In the novel attention has been paid to the fact of marginality. Carey's treatments of marginalized characters in this work make these novels postcolonial. The impacts of a corrupt culture of Voorstand upon the subjects of a small and less powerful country named Efica are depicted in the form of a Voorstandish Sirkus. There is an endeavor to reconcile with the past for the hope of acquiring a better future. But this quest is in vain. Tristan's attempt to restore friendly relation with his father brings to the surface lots of painful memories that haunt the future. So any compromise with the imperialism is the cause of later cultural dependency. The ideology of colonialism presents a clear view point about the problem of phalocentric ideology. All characters are entrapped within the structures imposed by the superpower Voorstand. The cultural relation between Efica and Voorstand is an important issue in the novel. It is a critique of the supremacy of Hollywood over the world entertainment industry.

\section{Discussion}

Carey's depiction of colonialism in Illywhacker and The Unusual Life of Tristan Smith present one of the clearest pictures of the structures of authority. The personal and social relationship in Illywhacker is plagued by a paralyzing overabundance of structure. The root of Carey's involvement with the issues of power, authority, and domination gets back to the novel Bliss (1981). In the novel Carey is more close to the ideas of Gramsci regarding to normality. But in Illywhacker he comes close to the idea of Jacques Lacan regarding to the Other.

In Illywhacker Carey wants to say that a subject in his search for subjectivity needs to learn how and what to desire. In Lacan's view also a subject in his struggle for achieving identity entangles in the argumentation with other. Illywhacker is a masterpiece of cultural, power, and postcolonial. At the same time it is a paradigm of the subject. Hence it can be seen a good model of the workings of human subjectivity. Herbert Badgery is a character who from the early childhood tries to repudiate the law of the Father. His dreams contain repressed material that manifests an ongoing account of the Other's presence. His childhood dream of making an Australian airplane wherein desire lurks reveals the discourse of the Other. He believes in Australia's potential for acquiring subjectivity. In one point Phoebe tells him unconsciously, "You have invented yourself, Mr Badgery, and that is why I like you. You are what they call a confidence man. You can be anything you want" (Carey, 1985, p. 91). Later on he discusses with Jack about Australia's dependency on the foreign countries. But his idea of achieving subjectivity later on becomes a delusion.

In the novel most of the characters are often not permitted to gain independence from the other. The problem is that they are not able to separate themselves and their desires from the Other. It reminds us of Lacan's observation of the child in his mirror stage. A child must acquire a unique experience or a recognition in which he will be able to distinguish between I and Other. It is in this crucial point in acquiring subjectivity that a subject acquires sense of the self as well. Unable to pass this stage a subject remains dependent for its entire life to other. It is in this stage that a child learns language as well. It is here that a child assumes himself a self-governing subject for the first time. This stage is called mirror stage and is very crucial for a child's sense of difference from the Other. In Lacanian psychology the first Other is father and a child who becomes later on a subject of the society must be able to distinguish between himself and the father. This experience creates 'libidinal dynamism' for him. But it is in the middle of such struggles that he makes the first glance of self-image. 'Ideal ego' Lacan believes will be achieved only by successfully passing this stage. This is a process of child's socialization. It is in this process that child becomes familiar with the Law which governs the mother's fantasies. Lacan names it the name of the Father. This name is the symbol of the Other. Lacan believes that we structure 
our desire based on this Other. In Lacanian psychoanalysis a subject leaves his association with the mother to live as an independent being under the Name of the Father. But the point is that the Law goes beyond its role and controls us within the symbolic realm. It is through our desire that we as subject are controlled and never permitted to achieve subjectivity.

The slave master ideology which permeates the novel is indicative of the primal father. It is through the different themes of the novel that we can get a bright view of illusory nature of subjectivity in the society. Themes such as exploitation, imprisonment, self-deception and its link to independence are abundant in the novel. Badgery signifies that a fraud ideology promotes the development of patriarchal dominion. It is conveyed not only in his role as narrator but also as an important character in the novel. Everything he says about the history of the country is lie. The point is that even he himself believes that the reader should not waste his time by searching for truth in the lines of the text. This way of storytelling links him with the hints about the settlers' history. His outcome as he is entangled in a cage as a specimen of the country brings to the light this fact that such way of life leads only to nothing. Badgery has a strong desire for believing his own lies and fictions. But at the same time is under the pressure of conscience which pushes him to return to the reality. As a whole, in Lacan's view point desire comes into the light through the interaction of language and culture. The only thing that creates differences between people is their different ways of the usage of language. It is the father that curbs the desire of the mother and converts it into the language. Subjects within an ideology can be likened to the players of a game: subjects think that, in negotiating the structure of the law to fulfill their desires, they are active players in the game. In reality, the game is playing them. Even the white male characters who want to get beyond the bounds of the Law are trapped; their belief in the ideology leads them to shun or annihilate anything that might endanger that ideology, leaving them no way out. As such we read in the novel,

"It is gold", Leah said, "that has led ordinary working men and women into terrible delusion; it has made them think that they can be the exception to ordinary working men and women all through history; it has made them think that all they need is luck. They have been blinded by gold. They have imagined that all they need to do is drive their pick into the right spot in the ground and they will be another Hannan-they'll bosses themselves. It has corrupted them. It has been the same with land. Men who spent their lives suffering from the ruling classes went out and stole land from its real owners. Hey, presto, I'm a boss. There has been no history here," she said. "The country has woken like a baby and had to discover everything for itself and only now are people learning what the ruling class has done to us, that we have been lied to an deceived about some working Man's paradise and we need more than luck to have freedom. (Carey, 1985, p. 229)

Carey's texts, most notably Illywhacker and The Unusual Life of Tristan Smith, depict this problem. In his texts characters run up against the boundaries of a white male hegemony, underscoring their inability to find any space outside the ideology that defines them. As Slavoj Zizek (1989) remarks that any attempts for the purpose of the removal of the ideology goes in vain because in the real sense it appears as a reality. Such a kind of reality always attempts for giving its subjects misinformation. Accordingly, the subject who recognizes the artificial nature of the limits of an ideology threatens the very existence of said ideology. Inherent in any ideology is a symptom. Many of Carey's characters are confronted, through symptoms of the American supremacist ideology, with its limits.

In The Unusual Life of Tristan Smith, Carey writes about an entertainment company named Sirkus, and the ways it is used for beguiling common people. The novel gives a clear picture of the impacts of global entertainment companies upon the psyches of the subjects. In the novel the impacts of Voorstand upon a small country named Efica remind us of colonial period. The impact of dominant ideology upon the life of common people has been brought to the surface in the light of Tristan Smith's life. Tristan is a disproportioned figure. It helps the reader to see the psychical impacts of ideology on the whole life of colonized subjects. His life in an insignificant country such as Efica is dominated by Voorstand ideology. Earlier this ideology is feared and disliked by his mother. His uncertain relationship with Mouse mask acknowledges that the dominant ideology is alluring for common subjects. He was a creature of his culture. A strange culture which is defamiliarized. He is depicted like an animal in a cage which resembles his society. He is able to achieve subjectivity only in the form of alienated character of Broder Mouse.

Efica is depicted like Australia while Voorstand quite stands for America. Through this Carey wants to inform the reader about the colonial role of America in Australia. The novel gives the impression that colonial dialogue still persists but altered in the form of cultural imperialism.

Carey's works benefits from the historical struggles that afford the Australian subject a unique consciousness as both object within the dominant ideology and subject within one's own secrete heart: double consciousness. As 
DuBois' (1989) idea with regard to the double consciousness that a person can get a glance about his self by the way others consider him. Carey, from the first novel to the present, has tended to celebrate the ways in which the veil empowers the Australian subject to negotiate subjectivity. Thus, where some characters like Herbert Badgery, internalize the Law-of-the-Father, Others-whom Carey highlights in some other novels-reject the idea of the self. Badger's fake dependence even dilapidates his relation with both Phobe and Leah. Woodcock believes, "Illywhacker depicts a particular phase of Australian culture and nationalism, a search for identity which went wrong. Carey conceived the novel as a survey through three generations, from the confidence man, 'a kind of degeneration from entrepreneurial capitalism', to 'the pet shop people."” (1996, pp. 57-58)

Characters deny the idea as object and develop an acute awareness of how to use the gaze to further hidden subjective desires. In this way, double consciousness is, paradoxically, a gift; it leads to a double voiced ness and the ability to signify. Like Herbert Badgery's lying, that does not suggest there is no truth. Herbert is a narrator who characterizes himself as a compulsive and inveterate liar. He thereby warns the reader to be wary and judicious in the search for truth. In fact, he is not really the liar he says he is -he even lies about that. He spends at least as much of his time contesting what he sees as the lies of Australian history as he does telling lies of his own. His dilemma is evident when he visits the O'Hagens, not really to sell them a Ford. He finally persuades Stu O'Hagen to buy the Ford, Herbert refuses to sell it, telling him with exasperated honesty to buy an Australian Summit instead.

"Not the Dodge. The Summit. It's the Summit you should have."

"What in the name of God is a Summit?" Stu shouted.

"A Car," I shouted back. "A vehide, made in Australia, An Australian

car."

"An Australian Car," O'Hagen said. "What a presumption."

"A what?"

"A presumption. Are you sitting there and telling me we can make a better

car than the Yanks? God Jesus Christ in Heaven help me ...

"It's not the point about better," I said, "it's a question of where the money

goes. You'd be better off with a worse car if the money stayed here."

$$
\begin{aligned}
& \text { "You're cock-eyed, man. You're a bloody hypocrite. You go around } \\
& \text { making a quid from selling the bloody things, and now you tell me I } \\
& \text { shouldn't buy one. You're making no sense," Stu sighed. (Carey 1985, pp. 72-73) }
\end{aligned}
$$

This example serves as a perfect instance of how double consciousness can lead to signifying. In this instance, we can see, through Badgery's conflicted argument about the preferability of an Australian Summit car, double consciousness allows for a self-consciousness separate from that gaze of contempt and pity.

Double consciousness has paved the way for a body of literature that has the ability to read the hegemonic, Western, white ideology from the outside. A literature whose characters already know they do not subscribe to the dominant ideology and so are not threatened by its symptoms or by any piece of the Real that lies outside of it. Carey's novels are filled with such characters. His novels seek to analyze the white male and American hegemony. They offer an alternate vision and version of living. The novels want not only to expose the boundaries of artificial ideologies but to transcend them, something his characters are aptly suited to do. Carey's characters are hardly ever under the illusion that the ideology offers any kind of truth or has the right to ask anything of them. Symptoms of Western hegemony are invited into Carey's novels and his character's lives, told to set a spell, feel comfortable, and offered a bite to eat. Not all of these pieces of the Real are beneficial, and not all are recognized for what they are at first. Nevertheless, all are accepted and all lead the protagonists, directly or indirectly, into a fuller understanding of who they are and who they may become, boundaries or no boundaries.

For instance, Tristan is confronted with different obstacles in his quest for subjectivity. These problems are related to the ideology under which he is inhabiting and some others are those Carey created to show dominant ideology in disguised form. His deformity can be considered as the impacts of colonial behavior upon the psyches of the native people. These natives are judged mostly because of their color and physical attributes. It reminds us of Lacan's notion of 'ego ideal'. This type of identification with bodily attributes reveals that the only liberation in such a kind of atmosphere is only submission to the prevailed ideology. Life in Efica for subjects 
like Tristan is full of tension because their death is impending. Carey challenges the readiness of the subjects who cooperate in their own impoverishment. It is shown in the connivance between Voorstand and Efica. The cultural relationship between these two countries highlights the law of the father. Characters such as Felicity, Roxanna Wilkinson, and Bill Millefleur are symbols of complicity with the law of the father. This is noteworthy that all their attempts to escape from the Other's dominion fail at the end.

According to Lacan, the Name of the Father, through laws expressed within the symbolic, maintains and shapes our desire: the structure of the law handed down by the Father upholds the organization of desire within the symbolic. If desire is a subject's primary motivation, then to control a subject's desires is to control that subject. In addition, since laws are culturally relative, they are part and parcel of ideology: laws shape and are shaped by ideologies. Ideologies, in turn, shape subjects. The ideology, from which the structure of the Law is issued, represents the control behind that structure - the Other by which we structure our desire.

For instance, when Tristan comes to Saarlim City he is disappointed because of bad quality of the life around there. This disappointment makes him to contemplate on the reasons behind their backwardness in this way, "We grow up with your foreignness deep inside our souls ... even when we beg you please to leave our lives alone, we admire you" (p.292). It clarifies that Tristan has recognized that the structures of cultural hegemony is very complicated. He says, "it was through your charm and your expertise that you conquered us, with your army ... but you kept us conquered with jokes and dancers, death and beauty" (p.294). Tristan plays a role in Voorstand Sirkus by which the dominant ideology preserves its supremacy. This company also plays a major role in colonizing Efican people culturally. That's why it resembles of American supremacy in political and cultural affairs. America is the primal father/master in the slaveholding Australia, and his name becomes emblematic of the Law and laws of that system. But Lacan also says that we inherit sin from the Father. In fact, the wording of the above quote says that we don't inherit the Law so much as we experience it as it "sustains the structure of desire" and that inheritance "the inheritance"-is the sin of the Father. If we read sin as a transgression of law, then we will see, as Tristan and Herbert do, that the Father has sinned against the principles that structure desire: the Law of the Father is one thing, and the inheritance is actually in opposition to it. The name of America, then, carries with it both the Law and the stain of sin against that Law. To understand the sin, we must first understand the Law.

The law of the slaveholding Australia is a law of race, gender, and economic exploitation; it controls both those in the novel who believe in it and those who do not. Under it, white males exploit both land and people to create and perpetuate an inheritance to pass down to their white sons. This should help us to see the way the law is inextricably tied to the sin: The primal father perpetrates crimes against the land and the natives.

As we see in Illywhacker, the wilderness, because it does not depend on the Law of the Father, servers as a place in which characters can re-imagine themselves outside the dominant ideology and possibly come to understand something outside the whole of the symbolic order. But, though the novel is able to imagine a space free of the Law, every attempt to celebrate this space as a place to know the Real is clouded by the way in which ideology encroaches upon it. The structure of the Law, in the name of economic gain, has always already defeated the wilderness. In addition, though Herbert Badgery tries to convince other about the ability of Australians in making their own aeroplane or car, he is never able to accomplish his dreams about this issue.

The Ford had been a tumour in my life. I had fought battles with it in the way another man might fight battles with alcohol or tobacco. I had walked away from it and returned to it. I had rejected it only to embrace it passionately. I admired its construction, its appearance, the skill that had produced it so economically. And these were also the things I loathed. (Carey, 1985, p. 75)

Illywhacker stands, then, as a novel that knows what it would take to escape both the Law and the sin of the Father but that does not imagine a successful getaway. The Law and sin become the curse that can never be, in Carey's world, eluded. Even Herbert Badgery, who tries desperately to escape from the tenets of that Law, or the commandments of the Subject, is at the same time making the gestures and actions of his subjection, all by himself. In trying to escape the sin of the Father, he searches for an alternate Father (a qualified, male teacher from whom he can learn a new ideology) and tries to father a son (so that he can pass on his learning to a male heir): he tries to escape the ideology by revising the ideology on its own terms. Louis Althusser's two definitions of "subject" illustrate precisely the paradox of the subject under the Law of the Father, "In the ordinary use of the term, subject infact means: 1) a free subjectivity, a centre of initiatives, author of and responsible for its actions; 2) a subjected being, who submits to a higher authority, and is therefore stripped of all freedom except that of freely accepting his submission." (Althusser, 1971, p. 182)

The terms of the ideology are, of course, phallocentric, which brings us back to Freud and Lacan. Althusser's 
Subject can be interpreted as Lacan's Other. An individual may be forced to submit to the dominant ideology, but without that free submission, the subject is able to see the illusory nature of the ideology more clearly. DuBois' definition of double consciousness illustrates this idea thus, "It is a peculiar sensation, this double consciousness, this sense of always looking at one's self through the eyes of others, of measuring one's soul by the tape of a world that looks on in amused contempt and pity" (DuBois, 1989, p. 3)

Even in describing the devastating effects of double consciousness on the psyche, which is split into two souls, DuBois recognizes and calls attention to the gift of second sight. Characters who confronted with a white, phallocentric organization of the symbolic that permits them only the space of other, are enabled to see behind the curtain. As a matter of fact, to lift the veil and uncover the imaginary nature of ideology.

\section{Conclusion}

In Lacanian psychoanalysis it is the Name of the Father that disallows subjects from acquiring subjectivity. In the same way in Carey's novels American ideology that permeates the novels frustrates characters attempts for achieving subjectivity. These novels chronicle the exercise of power over Australia by superpowers. In both of these novels Carey is aimed for reinventing the past. Because the story which was inherited regarding the history of the land is totally fake. In Lacanian terms, Badgery has chosen a different Father from the white Father (he is fighting against the Other, albeit on its own terms) as it is shown in these lines from the text:

This story concerns my father who I always imagined to be an Englishman, who made such a thing, as long as I knew him, of his Englishness, who never missed or chance to say, "I am an English man" or, "as an Englishman" that I was surprised to find out he was born in York Streets Warrnambool, the son of a shopkeeper. Yet for all that, I must carry his lie for him. For he made himself into an Englishman and my first memory of him is being chastised for the way I spoke. (Carey, 1985, p. 38)

Badgery is the first character mentioned in the story who finds a way out of the Law of the Father: he learns to exist within the symbolic but privilege the Real. The Real allows Badgery a ground for beginning again at zero and building an identity on his own terms. So subjects like Badgery and Tristan who inscribed into the symbolic, live under the name and law of the father. That's why the only liberation in Carey's fictional world is paternal dominion.

\section{References}

Althusser, L. (1971). Lenin and Philosophy and Other Essays. Trans. Ben Brewster. New York, NY: Monthly Review P.

Benjamin, J. (1988). The Bonds of Love: Psychoanalysis, Feminism, and the Problem of Domination. New York, NY: Pantheon.

Bowie, M. (1987). Freud, Proust and Lacan: Theory as Fiction. Cambridge: Cambridge University Press.

Bowie, M. (1991). Lacan. Cambridge: Harvard University Press.

Carey, P. (1985). Illywhacker. New York, NY: Vintage.

Carey. P. (1994). The Unusual Life of Tristan Smith. New York, NY: Vintage.

DuBoise, W. E. B. (1989). The Souls of Black Folk. New York, NY: Bantam.

Frye, N. (1976). The Secular Scripture: A Study of the Structure of Romance. Cambridge: Harvard University Press.

Hawley, J. (1981, September 26). How an Ad Man Found Bliss. Age, 26.

Ikin, V. (1977, January 1). Answers to Seventeen Questions: An Interview with Peter Carey. Science Fiction, 30-39.

Jackson, R. (1981). Fantasy: The Literature of Subversion. New York, NY: Methuen. http://dx.doi.org/10.4324/ 9780203328446

Lacan, J. (1990). The Four Fundamental Concepts of Psycho-analysis. (A. Sheridan, Trans.). New York, NY: Norton.

Lacan, J. (2004). Ecrits: A Selection. (A. Sheridan, Trans.). London: Routledge.

Lemaire, A. (1994). Jacques Lacan. (D. Macey, Trans.). London: Routledge.

Mellard, J. M. (1991). Using Lacan Reading Fiction. Urbana: University of Illinois Press.

Ragland-Sullivan, E. (1987). Jacques Lacan and the Philosophy of Psychoanalysis. Urbana: University of 
Illinois Press.

Woodcock, B. (1996). Peter Carey. Manchester: Manchester University Press.

Wright, E. (1984). Psychoanalytic Criticism: Theory in Practice. London: Methuen.

Zizek, S. (1989). The Sublime Object of Ideology. New York, NY: Verso.

\section{Copyrights}

Copyright for this article is retained by the author(s), with first publication rights granted to the journal.

This is an open-access article distributed under the terms and conditions of the Creative Commons Attribution license (http://creativecommons.org/licenses/by/3.0/). 